\title{
PERCEPATAN PENGEMBANGAN DESA WISATA BERBASIS PENDAMPINGAN MELALUI PELATIHAN HOMESTAY DAN PRAMUWISATA DI DESA PAKSEBALI
}

\author{
I Wayan Pantiyasa', I Made Trisna Semara² \\ ${ }^{12}$ Sekolah Tinggi Pariwisata Bali Internasional \\ pantiyasa@stpbi.ac.id, \\ semaratrisna@gmail.com
}

\begin{abstract}
Abstrak
Pembangunan pariwisata berkelanjutan yang berbasis kerakyatan, diperlukan upaya diversifikasi daya tarik wisata yang berorientasi pada peningkatan kesejahteraan masyarakat, pelestarian seni budaya, dan pembangunan kepariwisataan yang ramah lingkungan. Salah satu representasi dari pembangunan Pariwisata berbasis Masyarakat adalah pengembangan Desa Wisata. Sejalan Program Percepatan Pengembangan desa wisata yang dilaksanakan oleh Pemerintah melalui Kementerian Pariwisata bersinergi dengan Kementerian Desa, Pembangunan Daerah Tertinggal, dan Transmigrasi untuk mewujudkan 2.000 desa wisata, diharapkan peran Perguruan Tinggi dapat melakukan Pengabdian kepada Masyarakat untuk mendorong percepatan pengembangan desa wisata. Desa wisata yang akan dijadikan mitra dalam kegiatan Pengabdian kepada Masyarakat adalah Desa Wisata Paksebali, Kecamatan Dawan, Kabupaten Klungkung-Bali. Tujuan dari pengabdian ini adalah menghasilkan pramuwisata lokal yang kompeten dalam memandu wisatawan, menghasilkan sumberdaya manusia yang mampu mengelola dan melayani penyiapan akomodasi para wisatawan di homestay, meningkatkan kualitas dan kuantitas fasilitas yang memenuhi standar dan memahami pentingnya standar kriteria sehingga memenuhi syarat sesuai standar yang ditentukan pemerintah. Metodenya adalah melalui program pedampingan desa wisata dengan memberikan pelatihan pramuwisata dan penyiapan akomodasi/homestay. Sasaranya adalah warga masyarakat yang disiapkan oleh kelompok sadar wisata untuk menjadi pramuwisata dan warga masyarakat yang akan disiapkan rumahnya menjadi homestay. Program pendampingan ini memberikan dampak yang positif terhadap Desa Wisata Paksebali yakni 1) masyarakat mampu memandu, mampu menjelaskan daya tarik, dan mampu melayani wisatawan, 2) Homestay dapat dikelola dengan baik, lebih tertata rapi, bersih dan komunikasi serta koordinasi dengan pemandu wisata, penyedia makanan dan pemasaran lebih baik, 3) Desa wisata lebih confidence dalam memasarkan produk wisatanya dan mampu memberikan komando dan koordinaasi yang lebih baik dalam mengelola Desa Wisata.
\end{abstract}

Kata Kunci : homestay, pelatihan, pendampingan, dan pramuwisata 


\section{PENDAHULUAN}

Sektor pariwisata merupakan penggerak perekonomian masyarakat diharapkan dapat berjalan secara berkelanjutan melalui pengembangan pariwisata kerakyatan. Untuk mewujudkan pembangunan pariwisata berkelanjutan yang berbasis kerakyatan, diperlukan upaya diversifikasi daya tarik wisata yang berorientasi pada peningkatan kesejahteraan masyarakat, pelestarian seni budaya, dan pembangunan kepariwisataan yang ramah lingkungan. Pengembangan wisata seperti ini kini dikenal juga dengan istilah 'pariwisata pro-rakyat' (Putra \& Pitana, 2010).

Pengembangan pariwisata berbasis masyarakat semakin dianggap sebagai alternatif pariwisata yang berkelanjutan, karena menekankan keterlibatan aktif masyarakat setempat dalam pengembangan pariwisata. Community based tourism (CBT) adalah pariwisata yang memperhitungkan aspek keberlanjutan lingkungan, sosial dan budaya. CBT merupakan alat bagi pembangunan komunitas dan konservasi lingkungan atau dengan kata lain CBT merupakan alat bagi pembangunan pariwisata berkelanjutan (Suansri, 2003). Salah satu representasi dari pembangunan Pariwisata berbasis Masyarakat adalah pengembangan Desa Wisata. Pengembangan Desa Wisata pada saat ini terus didorong oleh Pemerintah melalui program yang digulirkan dalam kegiatan pariwisata di pedesaan dengan mengembangkan desa wisata sebagai program yang mampu mempercepat pertumbuhan baik ekonomi, sosial, budaya dan lingkungan.

Sejalan program percepatan pengembangan desa wisata yang dilaksanakan oleh Pemerintah melalui Kementerian Pariwisata bersinergi dengan Kementerian Desa, Pembangunan Daerah Tertinggal dan Transmigrasi untuk mewujudkan 2.000 desa wisata, diharapkan peran Perguruan Tinggi dapat melakukan Pengabdian kepada Masyarakat untuk mendorong percepatan pengembangan desa wisata.

Desa wisata yang akan dijadikan mitra dalam kegiatan Pengabdian kepada Masyarakat adalah Desa Wisata Paksebali. Desa Paksebali ini merupakan satu dari 18 Desa Wisata, Kabupaten Klungkung Provinsi Bali. Sebagai desa wisata yang terletak di lintasan jalan utama Denpasar-
Karangasem, daerah Paksebali memiliki akses yang baik dalam pengembangan pariwisata (Pantiyasa I. W., 2019). Berdasarkan hasil wawancara dan observasi Desa Paksebali diakui bahwa pengembangannya masih sangat lambat, hal ini disebabkan oleh kamampuan sumber daya manusia yang masih belum memiliki kompetensi di Bidang Pariwisata. Selain itu juga diakibatkan karena keterlibatan masyarakat belum dilakukan secara optimal dalam pembangunan desa wisata (Arianty \& Semara, 2018). Pengembangan pariwisata berbasis masyarakat dapat memberdayakan masyarakat pedesaan sehingga dapat menigktkan kesejahteraan warga desa (Pantiyasa I.W., 2011). Partisipasi masyarakat dalam pengembangan desa wisata dilakukan dari perencanaan, pembangunan sarana dan prasaran, pengelolaan dan monitoring serta evaluasi (Pantiyasa I. W., 2018). Pembentukan pokdarwis di Desa Wisata dan diorganisasi oleh Bumdes tentunya akan membangun sistem pengelolaan yang semakin baik di Desa Wisata. Akan tetapi kondisi pengelolaannya masih banyak permasalahan. Dalam pengembangannya mengalami beberapa kendala yaitu 1) Belum memiliki Pramuwisata sebagai pemandu wisata lokal bagi wisatawan yang berkunjung, 2) Belum memiliki Homestay dan sumber daya manusia untuk memberi pelayanan kepada wisatawan.

Tujuan yang ingin dicapai adalah 1) menghasilkan pramuwisata lokal yang kompeten dalam memandu wisatawan, 2) menghasilkan sumberdaya manusia yang mampu mengelola dan melayani penyiapan akomodasi para wisatawan di Homestay, meningkatkan kualitas dan kuantitas fasilitas yang memenuhi standar dan memahami pentingnya standar kriteria sehingga memenuhi syarat sesuai standar yang ditentukan pemerintah.

Tentunya dalam pembangunan desa wisata tidak lepas pada tiga faktor yaitu agama, manusia dan lingkungan (Semara, 2014). Tiga faktor ini merupakan kesatuan yang dinamis atar satu dengan lainnya yang saling melengkapi satu sama lainnya dan tidak saling mendahului yang sering di implementasikan dalam bentuk konsep Tri Hita Karana. Sehingga pembangunan desa wisata berkembang dengan sempurna. Dengan adanya supply yang baik dan ramah maka daerah itu akan menjadi daerah yang sangat baik untuk kunjungan kepariwisataan (Wijaya, Saputra, \& Semara, 2016). 


\section{METODE}

Sasaran pelatihan adalah warga masyarakat yang disiapkan oleh kelompok sadar wisata untuk menjadi pramuwisata dan warga masyarakat yang akan disiapkan rumahnya menjadi homestay. Targetnya adalah terdidiknya pramuwisata sebanyak 25 orang, dan terdidiknya tenaga pengelola dan pramugraha sebanyak 25 orang. Maksud Program ini adalah 1) mempercepat pengembangan desa wisata Paksebali, 2) meningkatkan peranan stakeholder dalam mengembagkan desa wisata Paksebali, 3) memasarkan produk desa wisata berupa paket wisata. Metode pelatihan yang dilakukan adalah coaching/pendampingan, teknik presentasi dan metode simulasi.

\section{HASIL DAN PEMBAHASAN}

\section{Pendampingan Desa Wisata}

Berdasarkan hasil survey dan kesepakatan dengan pokdarwis Desa Paksebali dan Kepala Desa Paksebali maka program pelatihan yang dilakukan sebagai berikut:

1. Pelatihan Pemandu Wisata dengan materi pelatihan yang diberikan adalah etika pemandu pariwisata, komunikasi pemandu wisata dan teknik memandu wisata

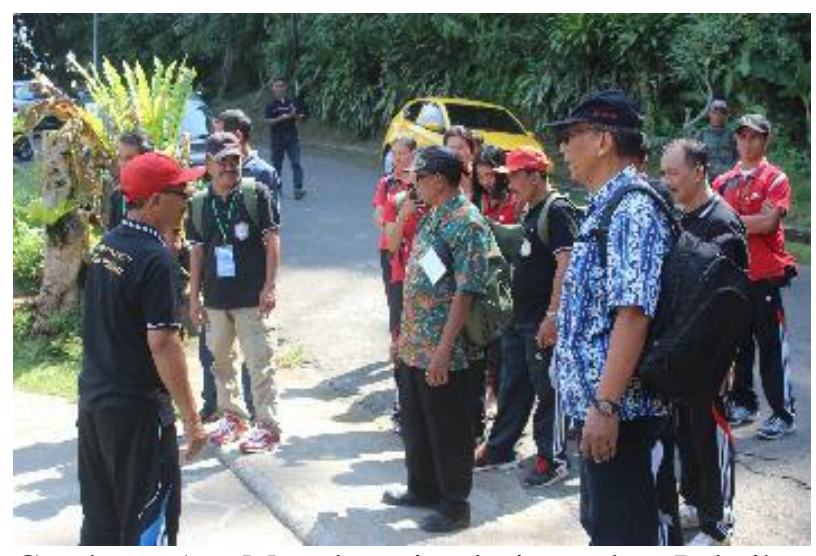

Gambar 1. Metode simulasi pada Pelatihan Pemandu Wisata

2. Pelatihan Penyiapan Akomodasi// Homestay dengan materi pelatihan yang diberikan adalah etika pramugraha persyartan homestay, sanitasi hygine, penyiapan kamar, dan teknik pembersih.

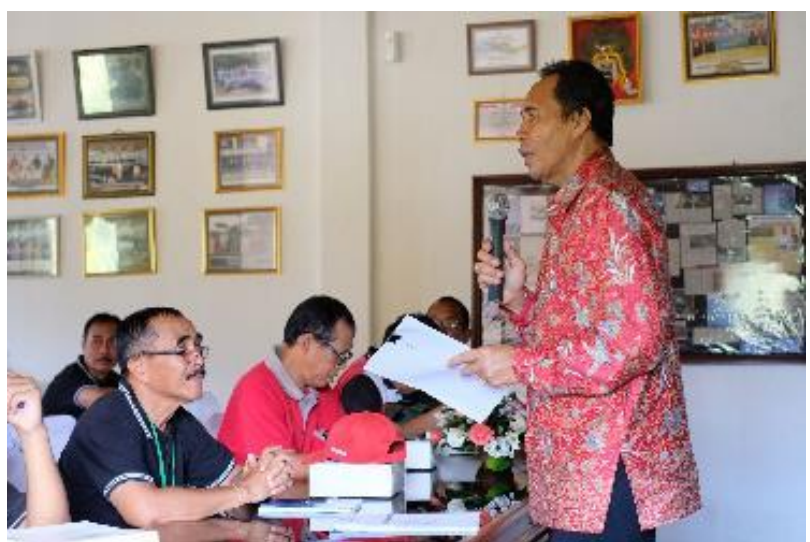

Gambar 2. Metode presentasi pada Pelatihan Penyiapan Akomodasi/Homestay

Ruang lingkup pelaksanaan kegiatan ini mencangkup pelatihan dan pendampingan, yang diadakan di Desa Wisata Paksebali bertempat di Kantor Desa Paksebali, Kecamatan Dawan, Kabupaten Klungkung. Adapun model pendampingan desa wisata yakni:

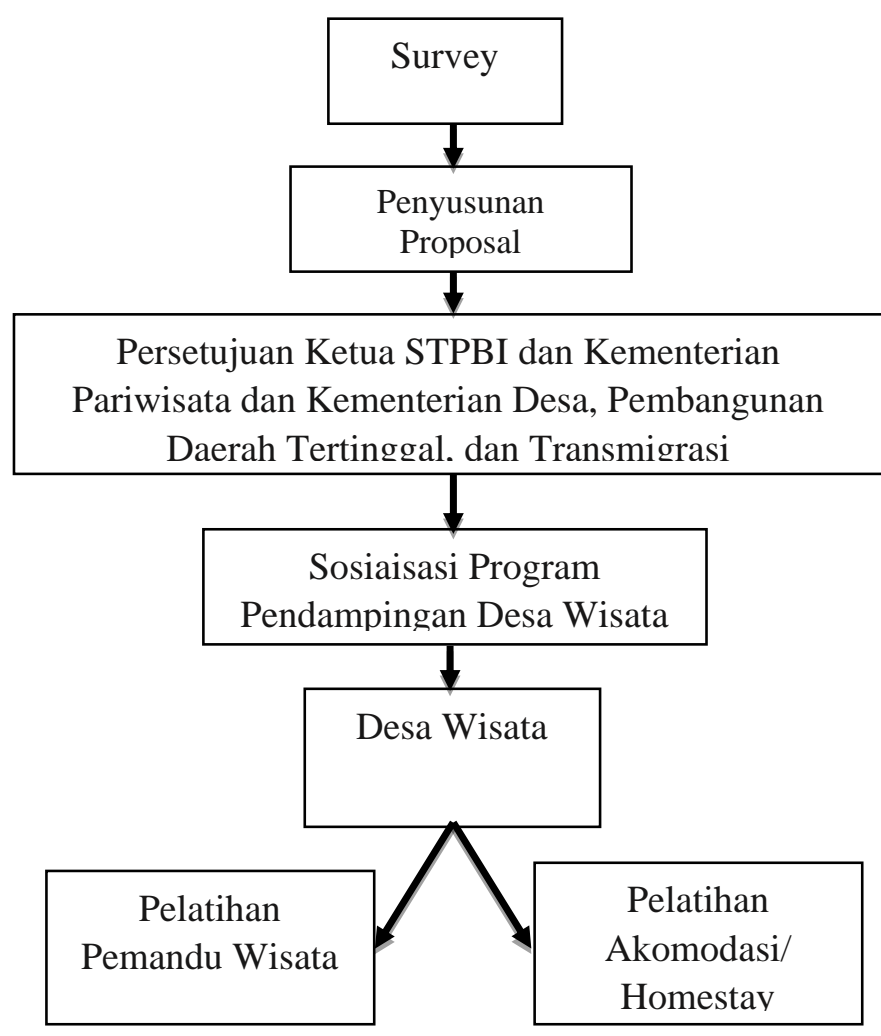

Gambar 3. Model Pendampingan Desa Wisata

$$
\text { Ekonomi, Sosial, dan Budaya }
$$


Kegiatan program ini terlaksana dengan baik dimana pelaksanaannya dapat berjalan dengan lancar. Hal ini dikarenakan didukung oleh beberapa pihak yakni dari Kementerian Pariwisata dan Kementerian Desa, Pembangaunan Daerah Tertinggal dan Transmigrasi. Pada penyelenggarkan kegiatan pengabdian kepada masyarakat bagi masyarakat Desa Paksebali dalam menyiapkan desa beserta potensi dan komunitasnya menjadi Desa Wisata yang mandiri dan unggul tidak terlepas dari keterlibatan Pokdarwis dan masyarakat dalam mengikuti kegiatan pelatihan. Hal ini menjadi perhatian, karena para wisatawan yang datang ingin menikmati keaslian dari kehidupan masyarakat desa, termasuk membaur dalam komunitas masyarakat dengan menginap di rumah-rumah penduduk.

Dalam hal pengelolaan, tim memberikan masukan agar selalu mengutamakan penyiapan kamar, hygine dan sanitasi lingkunagan yang berlandaskan pada konsep Tri Hita Karana dengan berbasis teknologi, untuk mempermudah memberikan pelayanan kepada wisatawan. Hal ini perlu karena menyangkut tingkat kepuasan tamu berkaitan hygine dan sanitasi kamar dan lingkungan. Metode pembersihan harus menggunakan alat-alat yang berstandar internasional baik dalam melakukan pembersihan, perawatan dan pemeliharaan interior dan ekterior homestay.

\section{Evaluasi Program}

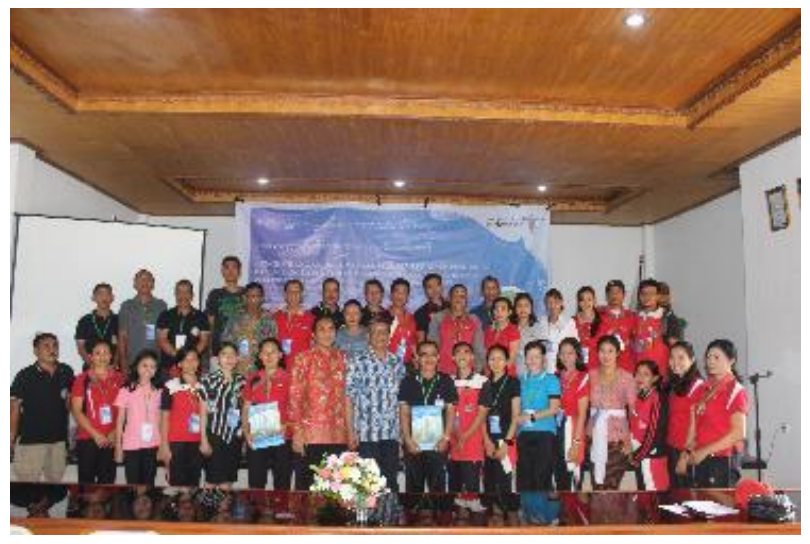

Gambar 4. Foto Bersama Pelatihan Pendampingan Desa Wisata
Berdasarkan keberhasilan program pendampingan desa wisata yang telah dilakukan dapat dikaji lebih mendalam dengan melakukan evaluasi melalui kuesioner terhadap kegiatan pelatihan. Kegiatan pelatihan pramuwisata dan homestay yang telah dilakukan berdasarkan evaluasi adalah berkatagori baik dengan rata-rata penilaian peserta pelatihan berdasarkan penyebaran kuesioner adalah sebesar 4,35. Untuk lebih jelasnya dapat dilihat pada gambar 1 .

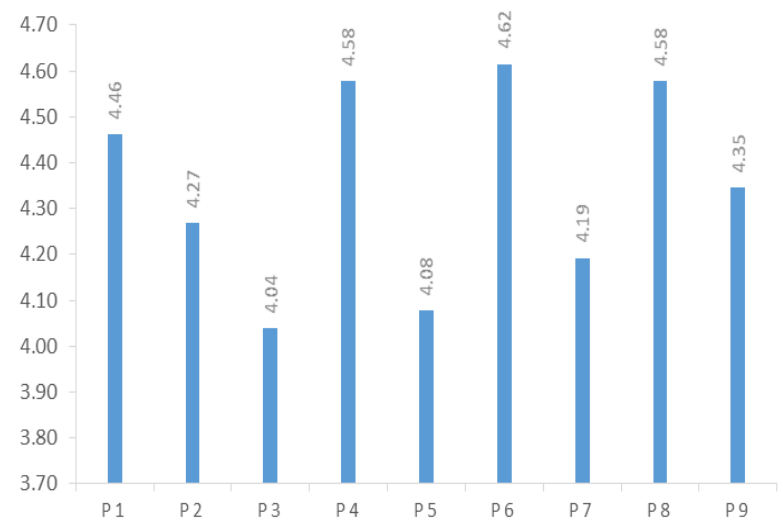

Gambar 5. Nilai Rata-rata Evaluasi Pelatihan Homestay dan Pramuwisata

Ada 3 (tiga) aspek pengukuran terhadap kegiatan pelatihan yakni 1) penilaian isi materi pelatihan, 2) penilaian penyampaian/penampilan materi, dan 3) penilaian diskusi/tanyajawab.

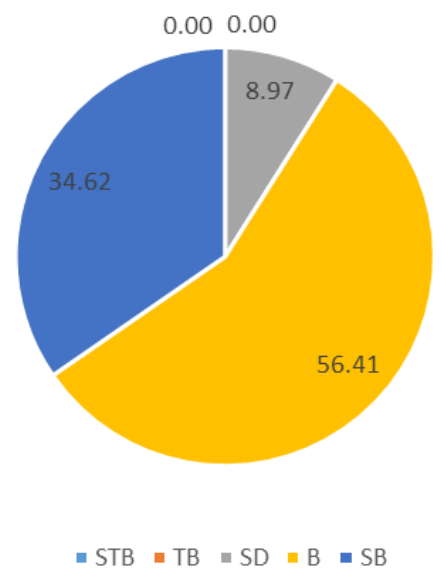

Gambar 6. Presentase penilaian Isi Materi Pelatihan

Pada aspek penilaian isi materi pelatihan memperlihatkan bahwa $91.03 \%$ peserta memilih katagori Baik dan Sangat Baik. Hal ini Ekonomi, Sosial, dan Budaya 1037 
memperlihatkan bahwa 1) materi terorganisasi dengan baik dan mudah dimengerti, 2) materi sangat relevan dan telah sesuai dengan yang diharapakan, 3) materi sudah mencukupi untuk mampu memahami pengelolaan desa wisata.

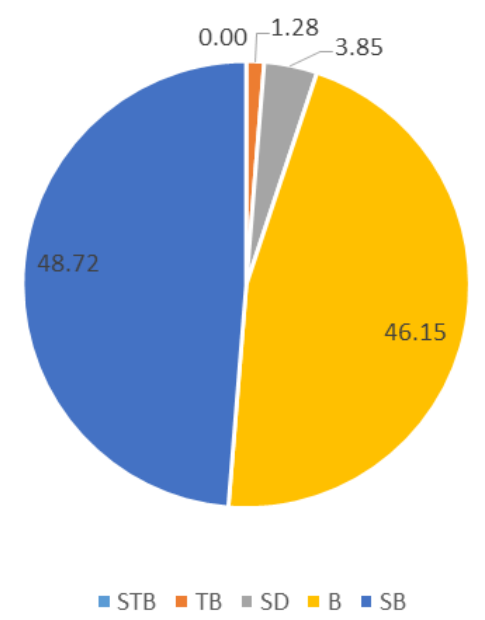

Gambar 7. Presentase penilaian Penyampaian/Penampilan Materi

Pada aspek penilaian penyampaian/ penampilan materi pelatihan memperlihatkan bahwa 94.87\% peserta memilih katagori baik dan sangat baik. Hal ini memperlihatkan bahwa 1) narasumber sangat memahami materi yang dipresentasikan, 2) alokasi waktu penyampaian materi mencukupi, 3) narasumber mempresentasikan isi materi dengan baik; mudah dimengerti dan diimplementasikan.

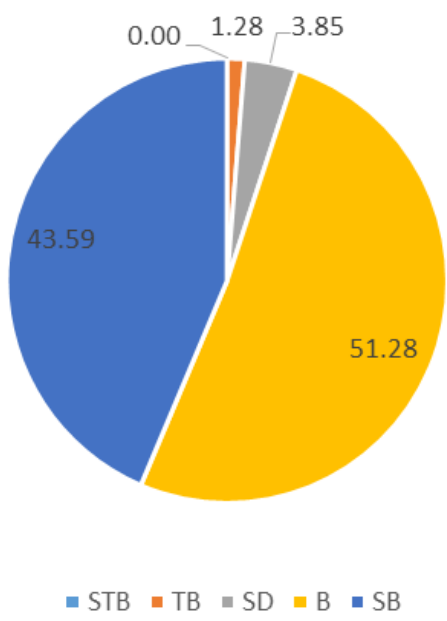

Gambar $\quad 8 . \quad$ Presentase penilaian Diskusi/Tanyajawab

Pada aspek penilaian sesi diskusi/ tanyajawab pada pelatihan memperlihatkan bahwa 94.87\% peserta memilih katagori baik dan sangat baik. Hal ini memperlihatkan bahwa 1) alokasi waktu diskusi mencukupi untuk menambah/ memperkuat pemahaman, 2) Narasumber memberikan jawaban terhadap pertanyaan peserta dengan baik, 3) secara keseluruhan diskusi/ tanyajawab telah sangat membantu meningkatkan pemahaman peserta.

\section{Dampak Program Pendampingan}

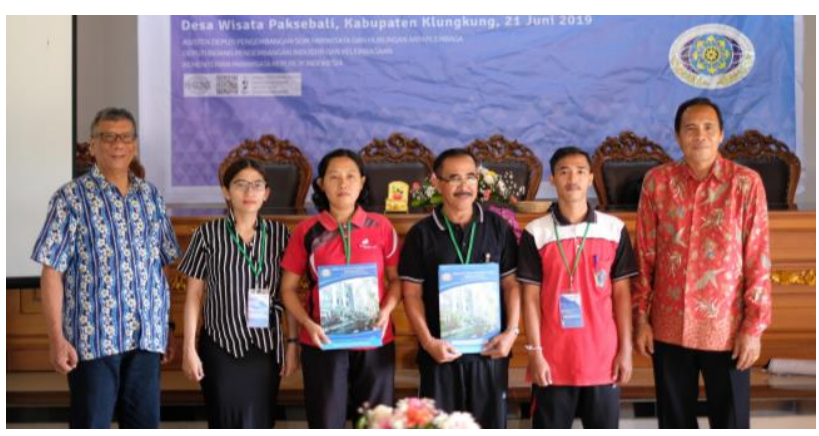

Gambar 9. Penyerahan Sertifikat Pelatihan

Dampak langsung dari program pendampingan Desa Wisata Paksebali ada 3 (tiga) yakni bagi peserta pramuwisata, pengelola homestay, dan pengelola Desa Wisata. Dampak program pelatihan terhadap Pramuwisata yakni 1) Pramuwisata lebih confidance dan mampu memandu wisatawan dengan baik, 2) Pramuwisata Mampu menjelaskan daya tarik wisata dengan lebih menarik, 3) Pramuwisata lebih sigap dalam membantu tamu, 4) Pramuwisata memiliki pengetahuan yang boleh dan tidak disampaikan /ditanyakan kepada tamu, 5) Pramuwisata berpenampilan lebih menarik. Dampak program pelatihan terhadap pengelola homestay yakni 1) Homestay dapat dikelola dengan baik sepeti; Penerimaan tamu, pencatatan tamu yang datang dan pulang (Check In and Check Out),

Ekonomi, Sosial, dan Budaya 
penyiapan /pembersihan kamar tamu, penanganan barang tamu tamu, 2) Home stay lebih tertata rapi dan bersih, 3) Komunikasi dan koordinasi dengan pemandu wisata, penyedia makanan dan bagian pemasaran lebih baik. Dan dampak program pelatihan terhadap Pengelolaan Desa Wisata yakni 1) Desa wisata lebih confidance dan lebih gencar memasarkan produk wisata terutama paket tour, 2) memiliki SOP yang dapat dipahami bagian yang melaksanakan, 3) Adanya pemahaman sistem oprasional lebih baik: komando dan Kordinasi berjalan lebih baik.

Berdasarkan program rintisan yang dilakukan dengan melibatkan civitas akademisi untuk merasakan pelayanan di Desa Wisata Paksebali, maka dapat disimpulkan bahwa pengelola desa wisata mampu beriteraksi dengan pengunjung (wisatawan), kualitas keahlian pramuwisata dan perjalanan wisata sudah sangat baik, kualitas pelayanan akomodasi sudah mulai berkembang dan mampu meberikan pengelolaan akomodasi yang berkualitas.

\section{SIMPULAN}

Simpulan pelaksanaan program pendampingan desa wisata di Desa Paksebali pada tahun 2019 telah dilaksanakan dengan baik dan sangat bermanfaat bagi pembangunan desa wisata Paksebali. Adapun dampaknya adalah 1) masyarakat mampu memandu, mampu menjelaskan daya tarik, dan mampu melayani wisatawan, 2) Homestay dapat dikelola dengan baik, lebih tertata rapi, bersih dan komunikasi serta koordinasi dengan pemandu wisata, penyedia makanan dan pemasaran lebih baik, 3) Desa wisata lebih confidence dalam memasarkan produk wisatanya dan mampu memberikan komando dan koordinaasi yang lebih baik dalam mengelola Desa Wisata.

\section{UCAPAN TERIMAKASIH}

Puji syukur kehadirat Tuhan Yang Maha Esa atas karunia-Nya yang telah diberikan, sehingga dapat menyelesaikan kegiatan pengabdian kepada masyarakat dengan baik. Ucapan terima kasih disampaikan kepada Ketua Sekolah Tinggi Pariwisata Bali Internasional yang sudah memotivasi dan memberikan dukungan terhadap terselesaikannya kegiatan pengabdian kepada masyarakat ini. Ucapan terima kasih juga disampaikan terhadap Kementerian Pariwisata dan Kementerian Desa, Pembangunan Daerah Tertinggal, dan Transmigrasi atas bantuan dana pengabdian yang telah diberikan sehingga kegiatan pengabdian kepada masyarakat dapat terlaksana dengan maksimal.

\section{REFERENSI}

Arianty, A. S., \& Semara, I. T. (2018). Persepsi Masyarakat terhadap Pengembangan Desa Wisata Pelaga sebagai Green Village Destination. Jurnal Ilmiah Hospitality Management, 27-32.

Pantiyasa, I. (2011). Pengembangan Pariwisata Berbasis Masyarakat (Community Based Tourism) dalam Pemberdayaan Masyarakat Studi Kasus di Desa Bedulu, Blah Batuh, Gianyar. Jurnal Ilmiah Hospitality Management, 12-21.

Pantiyasa, I. (2019). Konstruksi Model Pengembangan Desa Wisata menuju Smart Eco-Tourism di Desa Paksebali Klungkung, Bali. Jurnal Kajian Bali, 165-188.

Pantiyasa, I. W. (2018, September 30). Persepsi dan

Partisipasi Masyarakat dalam

Pengembangan Smart Eco-Village

Destination di Desa Wisata Paksebali untuk menjadi Ikon Pariwisata di Kabupaten Klungkung-Bali. Prosiding Meningkatkan Mutu Penelitian dan Peringkat Perguruan Tinggi, pp. 61-75.

Putra, I. D., \& Pitana, I. (2010). Pariwisata ProRakyat. Jakarta: Kementrian Kebudayaan dan Pariwisata.

Semara, I. M. (2014). Agama, Manusia dan Lingkungan sebagai Pondasi Daya Tarik Wisata di Objek Wisata Pura Tirta Empul, Tampak Siring, Gianyar, Bali. Jurnal Ilmiah Hospitality Management, 91-101.

Suansri, P. (2003). Community Based Tourism Handbook. Thailand: REST Project.

Wijaya, A. G., Saputra, I. D., \& Semara, I. T. (2016). Peran Lima Pilar Pengembangan Ekonomi, Sosial, dan Budaya 1039 
Pariwisata terhadap Kawasan Nusa Penida, Klungkung. Jurnal Ilmiah Hospitality Management, 51-58. 